Journal of Applied Veterinary Sciences, 7 (1): 38-45 (January, 2022).

ISSN: Online: 2090-3308, Print: 1687-4072

Journal homepage : https://javs.journals.ekb.eg

\title{
The Effect of Topically Applied Hyaluronic Acid on Skin Wound Healing in Rabbits
}

\author{
Ammar M. Rajab ${ }^{1 *}$ Ghada A. Taqa ${ }^{2}$ and Wael T. Al-Wattar ${ }^{3}$ \\ ${ }^{1}$ Ministry Of Health, Nineveh Health Directorate, Mosul, Iraq \\ ${ }^{2}$ Department of Dental Basic Science, College of Dentistry, University of Mosul, Mosul, Iraq. \\ ${ }^{3}$ Department of Oral and Maxillofacial Surgery, College of Dentistry, University of Mosul , Mosul, Iraq \\ *Corresponding Author: Ammar M. Rajab, E-Mail: ammar.dep4@student.uomosul.edu.iq
}

\begin{abstract}
This study aims to evaluate the effect of the topical application of hyaluronic acid cream $0.2 \%$ in the skin wound healing in rabbits. Thirty two healthy New Zealand adult male rabbits approximately at the same age and weight were involved in this study; all animals were anaesthetized using a $40 \mathrm{mg} / \mathrm{kg}$ ketamine and xylazine $4 \mathrm{mg} / \mathrm{kg}$ injection intramuscularly. The skin of the dorsum area of each rabbit was aseptically prepared and then two incisions $(1 \mathrm{~cm}$ in length) were made on the skin. Wounds were left without suturing to heal by secondary intention healing. Each animal had two wounds (wounds divided into two groups according to the type of treatment): one treated with hyaluronic acid cream twice a day, the second wound was left untreated. The application of the cream was repeated daily. Rabbits were divided into 4 groups according to sacrifice days; every eight rabbits were sacrificed in days 1st, 3rd, 7th, and 14th days, biopsies were taken and sent for histological assessment. Group treated with hyaluronic acid showed significant improvement in wound healing capacity in the skin of rabbits; granulation tissue formation and reepithelialization were significantly improved in the hyaluronic acid group compared with the control group in the 3rd and 7th days. Also, Reepithelialization in the hyaluronic acid group was better on the 14th day of this study compared with the control group. Hyaluronic acid cream increases the rate of wound healing in the skin of rabbits.
\end{abstract}

Original Article:

DOI:https://dx.doi.org/10.21608/javs.2 021.102235.1111

Received :21 October, 2021.

Accepted :01 December, 2021.

Published in January, 2022.

This is an open access article under the term of the Creative Commons Attribution 4.0 (CC-BY) International License . To view a copy of this license, visit:

http://creativecommons.org/licenses/by/4.0/

J. Appl. Vet. Sci., 7 (1 ): 38-45.

Keywords: Hyaluronic acid, Rabbits, Skin, Wound healing.

\section{INTRODUCTION}

The skin is the biggest organ in the human body and serves as a physical, chemical, and biological barrier. It is essential for living a healthy life. (Darwin et al., 2018). The skin is an important structure that protects interior organs from mechanical damage, microbial infection, UV light, and severe temperatures. (Rodrigues et al., 2019). The goal of topical wound treatment is to repair the wound as quickly as possible in order to reduce infection and decrease pain, discomfort, and scarring. An effective wound treatment should lower the quantity of necrotic tissue while also preventing microbial invasion. (Mayet et al., 2014).

Wound healing is one of the most complex processes, requiring the delicate synchronization of multiple distinct cell types in successive phases, including hemostasis, the inflammatory phase, the proliferative phase, and the remodeling phase. (Wang et al., 2018).

The wounded blood vessels constrict as an initial reaction to a wound. When platelets come into touch with exposed collagen and extracellular matrix, they release clotting factors to create a fibrin clot and growth factors to assist wound healing. (Clark., 2003). The fibrin clot stops blood flow and acts as a scaffold for arriving inflammatory cells; neutrophils are attracted first, followed by monocytes 48-96 hours later, which are converted into tissue-activated macrophages at the wound site. (Rodrigues et al., 2019).

Angiogenesis commences once the inflammatory phase finishes, and pericytes inside the basal lamina are activated, scaffolding and providing structural stability to the endothelial cells. (Ansell and Izeta, 2015). The clot is then invaded by fibroblasts, which migrate, proliferate, and create contractile granulation tissue, setting off the proliferative phase. 
Fibroblasts develop into myofibroblasts, which bring the wound borders together. (Martin, 1997). The dividing fibroblasts deposit a new extracellular matrix (ECM) and collagen. During the final remodeling phase, the newly laid collagen matrix becomes organized and cross-linked. Re-epithelialization takes place at the same time as unipotent epidermal stem cells proliferate from the basement membrane and terminally differentiated epidermal cells dedifferentiate. Numerous cell signaling events and cytokines are required to orchestrate these events (Donati et al., 2017).

Hyaluronic acid (HA) is a versatile, biocompatible, nonimmunogenic natural product (Sudha and Rose, 2019). It is a glycosaminoglycanrelated polysaccharide comprised of a basic unit of two sugars, glucuronic acid and $\mathrm{N}$-acetyl-glucosamine. HA has a large molecular mass in many human body regions, including the synovial fluid that surrounds joints, cartilage, and eye and skin tissues. (Neuman $e t$ al., 2015).

HA is found in humans, bovines, and roosters, as well as microbes. Commercially HA was initially isolated from Streptococcus bacteria spp. (Streptococcus zooepidemicus), followed by Bacillus spp., Lactococcus lactis, Agrobacterium sp., and Escherichia coli as hosts. HA is also found in mollusks and yeasts (Cryptococcus neoformans) (Liu et al., 2011; Fallacara et al., 2018).

Biocompatibility, biodegradability, mucoadhesivity, hygroscopicity, and viscoelasticity are some of the distinctive physicochemical features of HA. (Fallacara et al., 2018). HA influences cellular activity by preserving tissue integrity. It also plays many functions in repairing injured tissues and encouraging cell adhesion and differentiation during inflammation and embryonic development. (Jiang et al., 2007). This study aims to identify the role of topical application of HA on the acceleration of wound healing in rabbits.

\section{Animals:}

\section{MATERIALS AND METHODS}

The present study was performed in a total number of Thirty-two New Zealand adult male rabbits aged about 5-7 months, weighing $1.5-2 \mathrm{~kg}$. The animals were kept in the animal's house of the college of dentistry, Mosul University, Iraq. Animals were separated in plastic cages at room temperature $22 \pm 2$ $\mathrm{C}^{\circ}$, kept in 12 hours light, 12 hours dark, and free access to food and tap water.

\section{Material used:}

The hyaluronic acid cream used in this study has been brought from (fidia farmaceutici s.p.a., Abano Terme, Italy) as a commercial product named hyalu4skin cream, the main ingredient in this cream is hyaluronic acid $0.2 \%$.

\section{Surgical procedure:}

Each rabbit was given mixed $40 \mathrm{mg} / \mathrm{kg}$ ketamine (KETALROM-50, romvac company, SA) with xylazine (holland) $4 \mathrm{mg} / \mathrm{kg}$ injection intramuscularly in the thigh muscle of the rabbit (Ahirwar et al., 2021). The rabbit's weight is recorded using electronic digital scales; after 5-10 minutes. The rabbit reflexes were checked to ensure that anaesthesia was taken.

Animals in all groups were subjected to a septic preparation of the area of interest. Each animal was laid down in a prone position. A full-thickness $1 \mathrm{~cm}$ longitudinal skin incision was made. Each rabbit had two incisions on the skin of the dorsum area. All the defective wounds left without suturing to heal by secondary intentional healing.

Two stab incisions were made at the dorsum area through the skin of each rabbit, the first incision treated with HA cream, the second incision left without treatment. Wounds were divided randomly into two experimental groups; each group consisted of Thirty-two wounds according to the treatment material used.

- Group 1 (HA 0.2\%): Thirty-two Skin incisions treated with topical HA cream $0.2 \%$ two times daily.

- Group 2 (control): Thirty-two Skin incisions were left untreated.

Animals were subdivided into four groups according to the time of sacrifice. Eight animals have sacrificed on day 1 , day 3 , day 7 , and day 14 after the surgical procedure. Biopsies were collected and subjected to histopathological assessment.

\section{Histopathological scoring:}

Many authors like Sultana et al., (2009); Gupta et al., (2015) concluded histology scoring to evaluate the histopathology slide's healing status, which consists of three criteria: inflammatory cell infiltration, granulation tissue formation, and reepithelialization parameters. (Table 1,2 and 3).

Table 1: Criteria of the inflammatory response parameter

\begin{tabular}{|l|c|}
\hline Score 1 & $\begin{array}{c}\text { Nil No inflammatory cells were observed in } \\
\text { the field of surgery (X10). }\end{array}$ \\
\hline Score 2 & $\begin{array}{c}\text { Mild If inflammatory cells occur in low } \\
\text { numbers, less than } 1 / 2 \text { of the field (X10). }\end{array}$ \\
\hline Score 3 & $\begin{array}{c}\text { Moderate Inflammatory cells might be } \\
\text { observed in more than } 1 / 2 \text { of the field (X10). } \\
\text { Severe or abundant when inflammatory cells } \\
\text { exist in enormous numbers, greater than } 3 / 4 \\
\text { of the field (X10). }\end{array}$ \\
\hline
\end{tabular}




\section{The Effect of Topically Applied Hyaluronic Acid on ......}

Table 2: Criteria for the amount of granulation tissue formation.

\begin{tabular}{|c|c|}
\hline $\begin{array}{c}\text { Score } \\
1\end{array}$ & $\begin{array}{c}\text { Absent of granulation tissue development } \\
\text { in the wound. }\end{array}$ \\
\hline $\begin{array}{c}\text { Score } \\
2\end{array}$ & $\begin{array}{c}\text { The amount of granulation tissue } \\
\text { development in the wound gap is minimal. }\end{array}$ \\
\hline $\begin{array}{c}\text { Score } \\
3\end{array}$ & $\begin{array}{c}\text { The quantity of granulation tissue } \\
\text { development is moderate in tissues. }\end{array}$ \\
\hline $\begin{array}{c}\text { Score } \\
4\end{array}$ & $\begin{array}{c}\text { The total quantity of granulation tissue } \\
\text { development in the wound is profound. }\end{array}$ \\
\hline
\end{tabular}

Table 3: Criteria of re-epithelization parameters

\begin{tabular}{|c|c|}
\hline Score 0 & $\begin{array}{l}\text { Re-epithelialization along the margin of } \\
\text { the wound. }\end{array}$ \\
\hline Score 1 & $\begin{array}{l}\text { Re-epithelialization covers less than half } \\
\text { of the wound. }\end{array}$ \\
\hline Score 2 & $\begin{array}{l}\text { Re-epithelialization covering more than } \\
\text { half of the wound. }\end{array}$ \\
\hline Score 3 & $\begin{array}{l}\text { Re-epithelialization covers the whole } \\
\text { wound, uneven thickness. }\end{array}$ \\
\hline Sco & $\begin{array}{l}\text { Re-epithelialization covers the whole } \\
\text { wound, normal thickness. }\end{array}$ \\
\hline
\end{tabular}

\section{Statistical Analysis:}

The data were expressed as mean \pm standard deviation (S.D.), the variation between two experimental sets was statistically evaluated using the Mann-Whitney U test. Statistical significance was accepted for ( $\mathrm{p}$-value $\leq * 0.05)$.

\section{RESULTS}

In the present study, all the animals involved survived until the sacrifice days (1st,3rd,7th, and 14 days). In each sacrifice day of study, the biopsies were collected, slides prepared and stained by hematoxylin and eosin, and sent for histologists to assess histological scores (inflammatory response, granulation tissue formation, and epithelialization scoring).

\section{On the first day after surgery}

The inflammatory cell infiltration showed a similar result in both groups; both groups showed a moderate number of inflammatory cells in the field of operation, HA group showed a fewer amount of inflammatory cells, the mean of scores of histometric analysis for the control group and the HA group were $2.33 \pm 0.51,2.16 \pm 0.40$, respectively (Table 4; Figs. $1,5)$.

The granulation tissue was mainly absent in the control group slides sections. On the other hand, the HA group showed scanty to moderate granulation tissue response; the mean scores for granulation tissue formation in the control group and the HA group were $(1.833 \pm 0.40,2.33 \pm 0.51)$ respectively (Table 4) (Figure $1,6)$.

Table 4: Histopathological finding scores of skin wound healing at the first day (mean and standard deviation):

\begin{tabular}{|c|c|c|c|}
\hline Day 1 & $\begin{array}{c}\text { Inflammatory } \\
\text { C. I. }\end{array}$ & $\begin{array}{c}\text { Granulation } \\
\text { T. F. }\end{array}$ & $\begin{array}{c}\text { Re- } \\
\text { epithelialization }\end{array}$ \\
\hline Control & $2.3333 \pm$ & $1.8333 \pm$ & $0.0000 \pm$ \\
& 0.51640 & 0.40825 & 0.00000 \\
\hline Hyaluronic & $2.1667 \pm$ & $2.3333 \pm$ & $0.5000 \pm$ \\
acid & 0.40825 & 0.51640 & 0.54772 \\
\hline
\end{tabular}
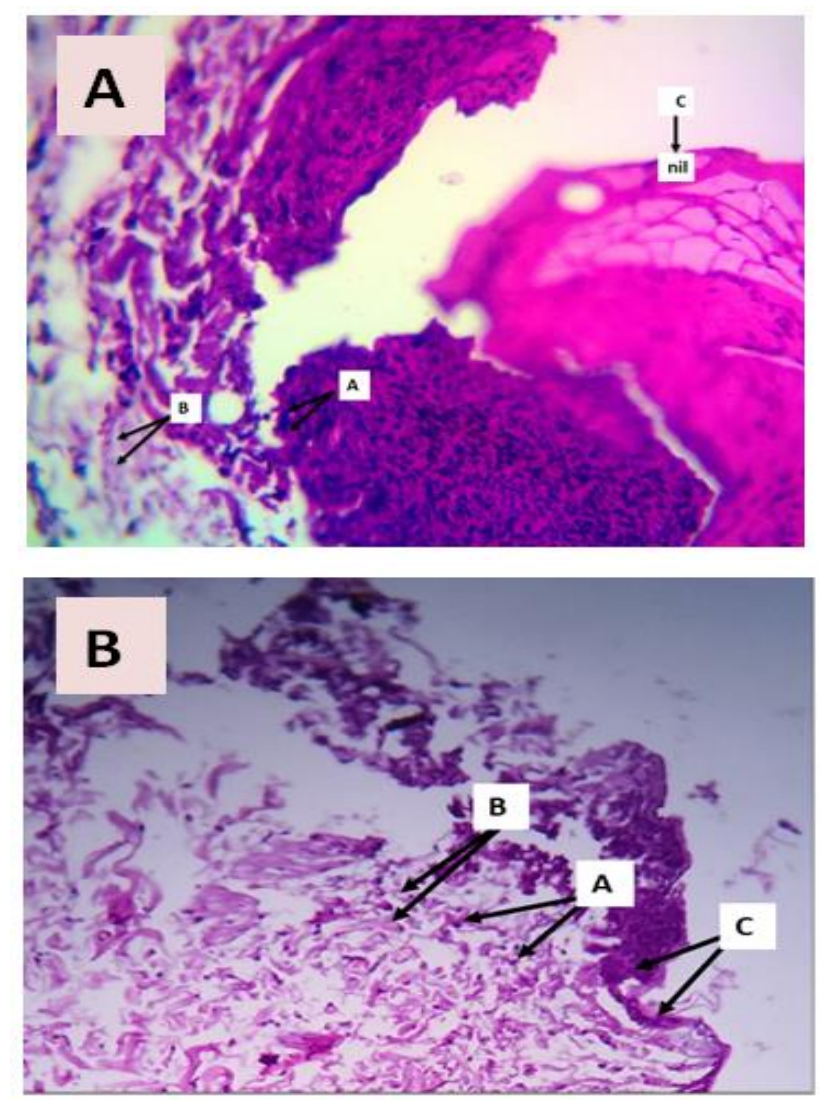

Fig. 1: Photomicrograph of skin wound in (A) control group and (B) hyaluronic acid at $1^{\text {st }}$ day.

A: inflammatory cell infiltration

B: granulation tissue formation

C: Re-epithelialization.

\section{On the third day after surgery:}

The inflammatory response in the Control group showed a mild inflammatory response. In contrast, slide sections of the HA group displayed a moderate inflammatory response. The mean score of inflammatory response was $(2.00 \pm 0.63)$ in the control group and $(2.8 \pm 0.75)$ in the hyaluronic acid group (Table 5 and Figs. 2,5). 
The granulation tissue assessment in the control group showed little granulation tissue in comparison to the HA group, which showed a moderate amount of granulation tissue, the mean score of granulation in the control group was $(1.166 \pm 0.40)$, while the mean of the HA group was $(2.833 \pm 0.40)$ (Table 5 and Figs. 2,6).

Re-epithelialization in the negative control group appeared covering less than half of the wound in some slides sections and some slides covering more than half of the wound. However, the HA group showed Re-epithelialization covering more than half the wound. The mean value of histological score was $(1.5 \pm 0.54)$ in control and $(2 \pm 0.0)$ in the HA group (Table 5; Figs. 2,7).

Two independent samples, Mann-Whitney U Test, revealed a non-significant difference in inflammatory response between groups and a significant difference in granulation and Reepithelialization between the HA and control groups. The HA group exhibited a greater rate of granulation tissue development and a significant increase in Reepithelialization.

Table 5: Histopathological finding scores of skin wound healing at the 3rd day (mean and standard deviation):

\begin{tabular}{|l|c|c|c|}
\hline Day 3 & $\begin{array}{c}\text { Inflammatory } \\
\text { C. I. }\end{array}$ & $\begin{array}{c}\text { Granulation } \\
\text { T. F. }\end{array}$ & $\begin{array}{l}\text { Re- } \\
\text { epithelialization }\end{array}$ \\
\hline control & $2.0000 \pm$ & $1.1667 \pm$ & $1.5000 \pm$ \\
& 0.63246 & 0.40825 & 0.54772 \\
\hline hyaluronic & $2.8333 \pm$ & $2.8333 \pm$ & $2.0000 \pm$ \\
acid & 0.75277 & 0.40825 & 0.00000 \\
\hline
\end{tabular}
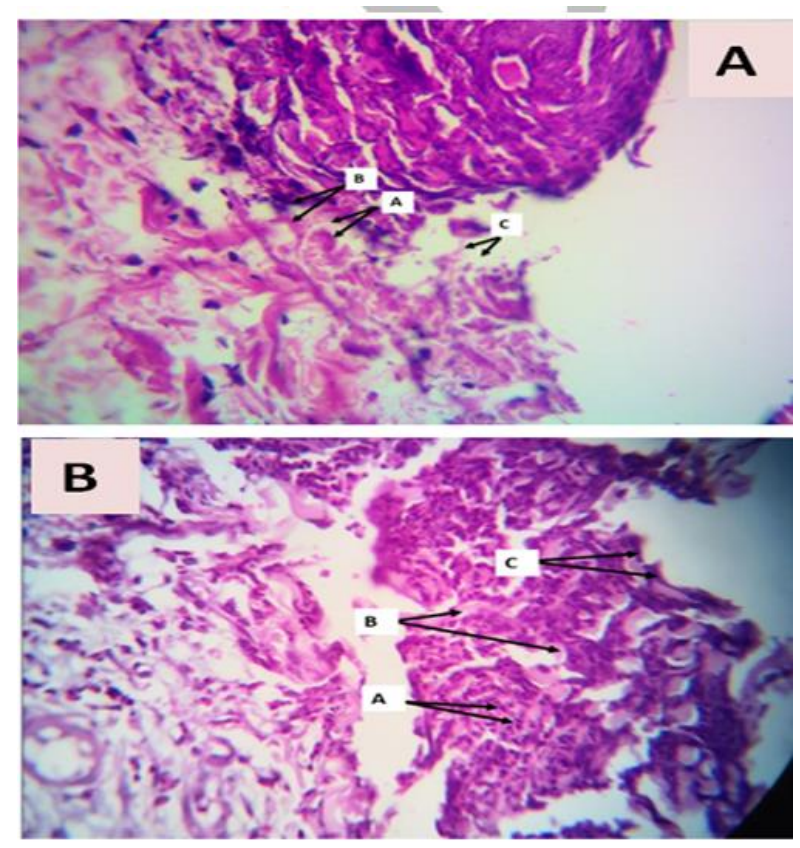

Fig. 2: Photomicrograph of skin wound in (A) control group and (B) hyaluronic acid at 3rd day.

A: inflammatory cell infiltration. B: granulation tissue formation. C: Re-epithelialization.
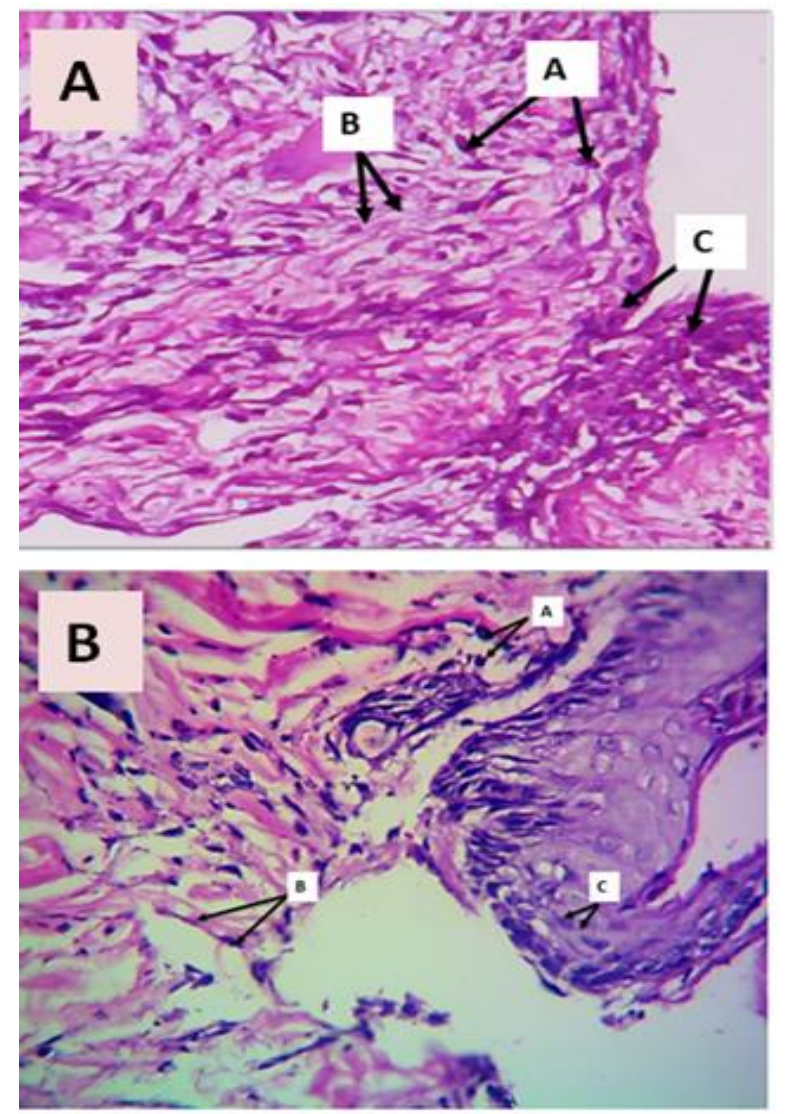

Fig. 3: Photomicrograph of skin wound in (A) control group and (B) hyaluronic acid at $7^{\text {th }}$ day.

A: inflammatory cell infiltration.

B: granulation tissue formation.

C: Re-epithelialization.

\section{At one week after surgery:}

The control group appeared nil in the inflammatory response in some slides and mild in others; some slides of HA showed nil inflammatory cell infiltrate and some showed a mild response; the mean score for HA was $(1.33 \pm 0.51)$. The mean score of inflammatory cell infiltrate in HA was $(1.66 \pm 0.51)$. (Table 6 and Figs. 3,5).

The Control group displayed scanty granulation tissue in most of the slides. In contrast, Hyaluronic acid slide sections were distributed between a scanty and moderate amount of granulation tissue. The mean value of granulation tissue in the control group was $(1.833 \pm 0.40)$, and in the HA group was (2.5 \pm 0.54$)$ (Table 6 and Figs. 3.6).

The Control group displayed reepithelialization covering more than half of the wound in almost all slides; the HA group showed good result translated by re-epithelialization covering the entire wound irregular thickness in almost all slides in this group, the mean score of the histological investigation was $(2 \pm 0.0)$ in the control group. It was $(2.83 \pm 0.75)$ in the HA group (Table 6 and Figs. 3,7).

Two independent sample Mann-Whitney U Test revealed a non-significant difference in inflammatory response between groups on the 7th day 
of surgery, also revealed a significant difference in granulation and Re-epithelialization between HA group and control group, the HA group exhibiting a greater rate of granulation tissue development and a significant increase in re-epithelialization.

Table 6: Histopathological finding scores of skin wound healing at the $7^{\text {th }}$ day (mean and standard deviation):

\begin{tabular}{|l|c|c|l|}
\hline Day 7 & $\begin{array}{c}\text { Inflammatory } \\
\text { C. I. }\end{array}$ & $\begin{array}{c}\text { Granulation } \\
\text { T. F. }\end{array}$ & $\begin{array}{l}\text { Re- } \\
\text { epithelialization }\end{array}$ \\
\hline control & $1.6667 \pm$ & $1.8333 \pm$ & $2.0000 \pm$ \\
& 0.51640 & 0.40825 & 0.00000 \\
\hline Hyaluronic & $1.3333 \pm$ & $2.5000 \pm$ & $2.8333 \pm$ \\
acid & 0.51640 & 0.54772 & 0.75277 \\
\hline
\end{tabular}

\section{At two weeks after surgery:}

The inflammatory infiltration in both groups ranged from nil to moderate control group inflammatory response score was $(1.33 \pm 0.51)$, the mean score of HA was $(1.166 \pm 0.40)$ (Table 7 and Figs. 4,5).

Both groups at this day showed a closely similar amount of granulation tissue formation; scanty granulation tissue appeared prevalent in most slides sections of both groups. Histological scores of the Control group and HA group were $(2 \pm 0.63)$, (2.166 \pm 0.75 ), respectively (Table 7 and Figs. 4,6).

In this period of the study, the reepithelialization in the control group displayed reepithelialization covering more than half of the wound with some slides showing the entire wound covering with irregular thickness; HA group showed Reepithelialization covering the entire wound with normal thickness. The Control group histological score was $(2.66 \pm 0.51)$ while the HA group score was (3.66 \pm 0.51$)$ (Table 7 and Figs. 4,7).

Two independent samples, Mann-Whitney U Test, revealed a non-significant difference in inflammatory response and granulation between groups on the 14th day of surgery, also revealed a significant difference in Re-epithelialization between HA group and control group, the HA group exhibiting faster Re-epithelialization.

Table 7: Histopathological finding scores of skin wound healing at the 14th day (mean and standard deviation).

\begin{tabular}{|l|c|c|c|}
\hline Day 14 & $\begin{array}{c}\text { Inflammatory } \\
\text { C. I. }\end{array}$ & $\begin{array}{c}\text { Granulation } \\
\text { T. F. }\end{array}$ & $\begin{array}{c}\text { Re- } \\
\text { epithelialization }\end{array}$ \\
\hline control & $1.3333 \pm$ & $2.0000 \pm$ & $2.6667 \pm$ \\
& 0.51640 & 0.63246 & 0.51640 \\
\hline Hyaluronic & $1.1667 \pm$ & $2.1667 \pm$ & $3.6667 \pm$ \\
acid & 0.40825 & 0.75277 & 0.51640 \\
\hline
\end{tabular}

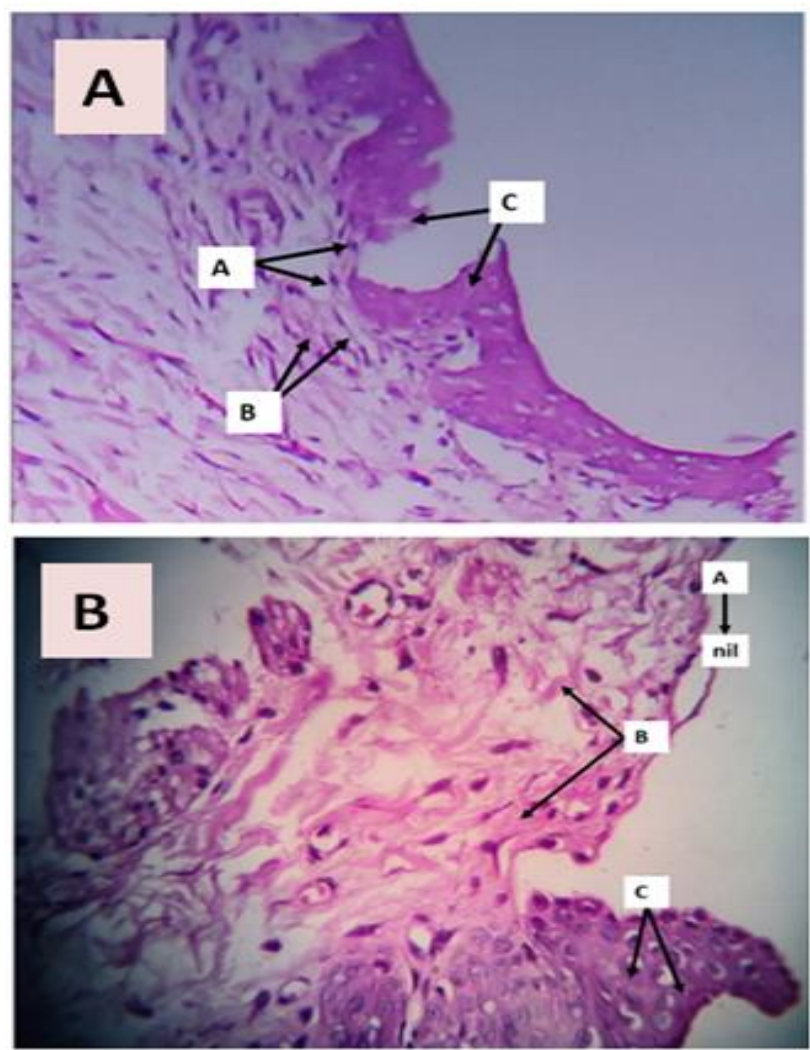

Fig. 4: Photomicrograph of skin wound in (A) control group and (B) hyaluronic acid at $14^{\text {th }}$ day.

A: inflammatory cell infiltration

B: granulation tissue formation

C: Re-epithelialization.

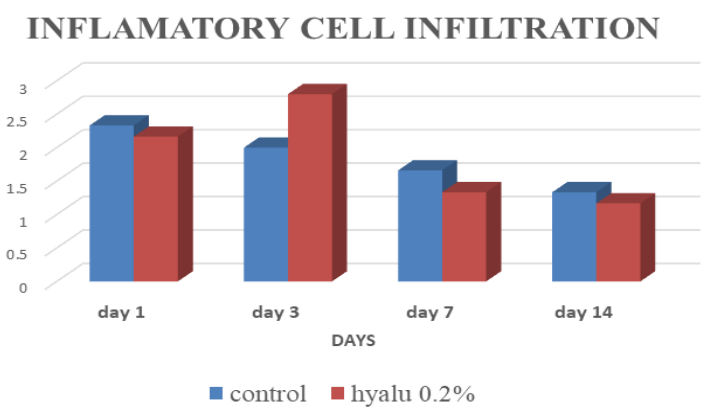

Fig. 5: Inflammatory cell infiltration Scoring at 1st,3rd, 7th, and 14th Days after Incisions.

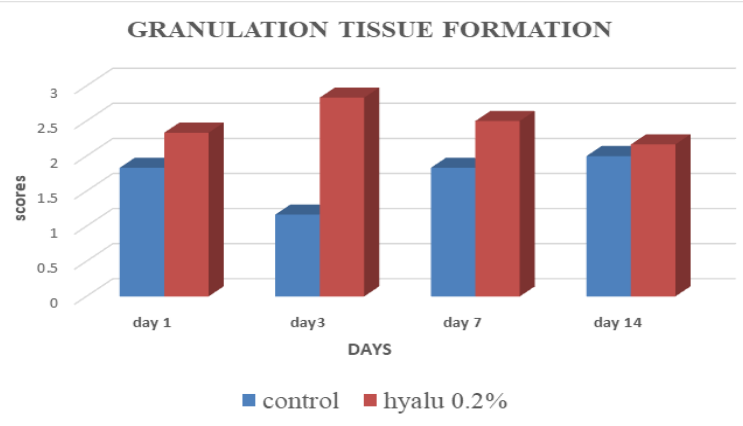

Fig. 6: Granulation tissue formation Scoring at 1st, 3rd,7th, and 14th Days after Incisions. 
In the control group, re-epithelization was at the edge of the wounds. At the same time, some of the HA slides showed re-epithelization covering less than half of the wound, the mean values of reepithelialization scores for control and the HA group were $(0 \pm 0.0,0.5 \pm 0.54)$, respectively (Table 4 and Figs. 1,7). Two independent samples, Mann-Whitney U Test, revealed no significant difference between inflammatory, granulation, and re-epithelialization groups.

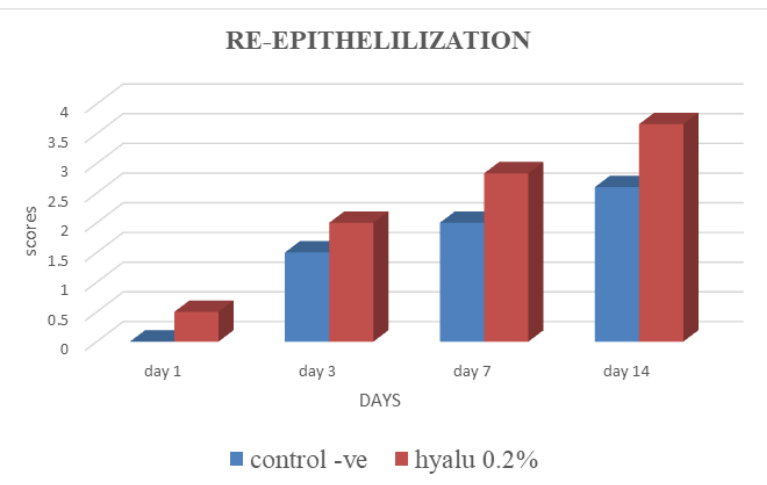

Fig. 7: Re-epithelization Scoring at 1st,3rd,7th, and 14th Days after Incisions.

\section{DISCUSSION}

Wound healing is critical for survival: it begins soon after damage with hemostasis and seeks to re-establish the epithelial barrier. Following hemostasis, it goes via a series of partially overlapping steps: inflammation, proliferation, and remodeling. The entire process is fragile and vulnerable to interruption, failure, or change, resulting in the creation of non-healing chronic wounds or fibrotic scars and increasing the risk of infection, eventually causing patient morbidity. (Cialdai et al., 2017).

Hyaluronic acid, as an extracellular matrix component, is essential in all stages of wound healing, encouraging cell migration, differentiation, and proliferation while also controlling extracellular matrix architecture and metabolism. (Chen et al., 2019)

In this study, the inflammatory cell infiltrate in the hyaluronic acid group reached the peak on the third day of study then declined during the next two weeks of the healing process; there was no significant difference $(p \leq 0.05)$ between the hyaluronic acid group and control group in the inflammatory response, which suggest that the mechanism of action of HA does not affect on inflammatory response during the wound healing process. This result came to parallel with Nyman et al., (2019), who discovered no significant effect for HA on the inflammatory response.
The results of the present study demonstrated that wounds topically treated with HA had enhanced wound healing by enhancing granulation tissue formation, which was significantly increased on the third and seventh day of the study compared to the control group. This result came to parallel with the result of Chen et al., (2019) After applying HA, he discovered a significant increase in Ki-67 expression, particularly in fibroblasts and the basal epidermal layers, as well as a significant increase in VEGF expression in the wound margin area. $\mathrm{He}$ also discovered that prolyl 4-hydroxylase expression was significantly elevated in the peri-wound edge, particularly in endothelial cells and fibroblasts., all these factors enhance granulation tissue formation and maturation.

Also, Scarano et al., (2021) found similar findings in his study when he administered HA via dermis injection technique, HA stimulated fibroblast activity, and the synthesis of Type III reticular collagen. Also, HA increased angiogenesis, epidermis thickness with the stratum basal cells' augmentation and increased the Epidermal Growth Factor (EGF).

HA increases the formation of CD44 receptors and improves its enzymolysis, encouraging angiogenesis, increasing collagen expression, and reducing the ratio of collagen types I and III, all of which increase the strength and flexibility of the afflicted skin. ( Zhao et al,.2013; Canciani et al., 2021)

The wounds in this study left to heal secondary intentional healing, the gap in the wound bed filled with a layer fibrin clot. Çankaya et al., (2020) observed that topical HA application on free gingival graft enhances the formation of a wellvascularized layer that works as a scaffold between the donor and recipient sites during the early phases of wound healing, acting as a barrier against tissue tensions leading to promote wound healing process.

The present study showed that HA significantly increased Re-epithelialization in the 3rd,7th, and 14th day, histological evaluation of hyaluronic acid group these results came in concordance with Gao et al., (2019) who demonstrated that the application of HA has the potential of enhancing Re-epithelialization and angiogenesis in the wounds of rats models.

Also, Yıldırım et al., (2018) noticed that topical HA periodontal dressing reduces post-operative discomfort and accelerates epithelization of the palatal donor wound sites. So HA application led to tissue maturation and rapid epithelization and ensured a good 
Color Match. Nyman et al., (2019), in their study on the skin, he concluded that exogenous intradermal HA promotes re-epithelialization and changes protein expression in human in vivo deep dermal skin wounds.

\section{CONCLUSION}

Hyaluronic acid cream is considered an ideal material due to its biodegradability and biocompatibility with the skin; hyaluronic acid has a beneficial effect on the acute wound healing process through enhancing granulation tissue formation and reepithelialization.

\section{Declaration of Conflicting Interests}

The authors revealed that there is no potential conflicts of interest.

\section{REFERENCES}

AHIRWAR, LK, KALRA, P., SHARMA, S., MOHAMED, A., MITTAL, R., DAS, S., and BAGGA, B., 2021. Linezolid shows high safety and efficacy in the treatment of Pythium insidiosum keratitis in a rabbit model. Experimental Eye Research, 202, p.108345.

https://doi.org/10.1016/j.exer.2020.108345

ANSELL, D.M., and IZETA, A., 2015. Pericytes in wound healing: friend or foe? Experimental dermatology, 24(11), pp.833-834.

https://doi.org/10.1111/exd.12782

CANCIANI, E., SIREllo, R., PELlegrini，G., HENIN, D., PERROTTA, M., TOMA, M., KHOMCHYNA, N., and DELLAVIA, C., 2021. Effects of Vitamin and Amino Acid-Enriched Hyaluronic Acid Gel on the Healing of Oral Mucosa: In Vivo and In Vitro Study. Medicina, 57(3), p.285. https://doi.org/10.3390/medicina57030285

ÇANKAYA, Z.T., GÜRBÜZ, S., BAKIRARAR, B., and KURTIŞ, B., 2020. Evaluation of the Effect of Hyaluronic Acid Application on the Vascularization of Free Gingival Graft for Both Donor and Recipient Sites with Laser Doppler Flowmetry: A Randomized, Examiner-Blinded, Controlled Clinical Trial. International Journal of Periodontics \& Restorative Dentistry, 40(2). https://doi.org/10.11607/prd.4494

CHEN, R.F., WANG, C.T., CHEN, Y.H., CHIEN, C.M., LIN, S.D., LAI, C.S., WANG, C.J., and KUO, Y.R., 2019. Hyaluronic acid-povidone-iodine compound facilitates diabetic wound healing in a streptozotocin-induced diabetes rodent model. Plastic and reconstructive surgery, 143(5), pp.1371-1382. https://doi.org/10.1097/prs.0000000000005504

CIALDAI, F., VIGNALI, L., MORBIDELLI, L., COlCIAGo, A., CElotTI, F., SANTI, A., CASELLI, A., CIRRI, P., and MONICI, M., 2017. Modelled microgravity affects fibroblast functions related to wound healing. Microgravity Science and Technology, 29(1-2), pp.121-132. https://doi.org/10.1007/s12217-016-9532-7

CLARK, R.A. 2003. Fibrin is a many splendored things. Journal of Investigative Dermatology, 121, pp.xxixxii.https://doi.org/10.1046/j.1523-1747.2003.12575.x
DARWIN, E., and TOMIC-CANIC, M., 2018. Healing chronic wounds: current challenges and potential solutions. Current dermatology reports, 7(4), pp.296302. https://doi.org/10.1007/s13671-018-0239-4

DONATI, G., ROGNONI, E., HIRATSUKA, T., LIAKATH-ALI, K., HOSTE, E., KAR, G., KAYIKCI, M., RUSSELL, R., KRETZSCHMAR, K., MULDER, K.W., and TEICHMANN, S.A., 2017. Wounding induces dedifferentiation of epidermal Gata6+ cells and acquisition of stem cell properties. Nature cell biology, 19(6), pp.603-613. https://doi.org/10.1038/ncb3532

FALLACARA, A., BALDINI, E., MANFREDINI, S., and VERTUANI, S., 2018. Hyaluronic acid in the third millennium. Polymers, 10(7), p.701. https://doi.org/10.3390/polym10070701

GAO, Y., SUN, Y., YANG, H., QIU, P., CONG, Z., ZOU, Y., SONG, L., GUO, J., and ANASTASSIADES, T.P., 2019. A low molecular weight hyaluronic acid derivative accelerates excisional wound healing by modulating pro-inflammation, promoting epithelialization and neovascularization, and remodeling collagen. International journal of molecular sciences, 20 (15), p.3722. https://doi.org/10.3390/ijms20153722

GUPTA, A., and KUMAR, P., 2015. Assessment of the histological state of the healing wound. Plastic and Aesthetic Research, 2, pp.239-242. https://doi.org/10.4103/2347-9264.158862

JIANG, D., LIANG, J. and NOBLE, PW, 2007. Hyaluronan in tissue injury and repair. Annu. Rev. Cell Dev. Biol., 23, pp.435-461. https://doi.org/10.1146/annurev.cellbio.23.090506.123337

LIU, L., LIU, Y., LI, J., DU, G., and CHEN, J., 2011. Microbial production of hyaluronic acid: current state, challenges, and perspectives. Microbial cell factories, 10(1), pp.1-9. https://doi.org/10.1186/14752859-10-99

MARTIN, P. 1997. Wound healing--aiming for perfect skin regeneration. Science, 276(5309), pp.75-81. https://doi.org/10.1126/science.276.5309.75

MAYET, N., CHOONARA, YE, KUMAR, P., TOMAR, LK, TYAGI, C., DU TOIT, L.C., and PILLAY, V., 2014. A comprehensive review of advanced biopolymeric wound healing systems. Journal of pharmaceutical sciences, 103(8), pp.2211-2230. https://doi.org/10.1002/jps.24068

NEUMAN, M.G., NANAU, R.M., ORUÑA-SANCHEZ, L., and COTO, G., 2015. Hyaluronic acid and wound healing. Journal of pharmacy \& pharmaceutical sciences, 18(1), pp.53-60. https://doi.org/10.18433/J3K89D

NYMAN, E., HENRICSON, J., GHAFOURI, B., ANDERSON, C.D., and KRATZ, G., 2019. Hyaluronic acid accelerates re-epithelialization and alters protein expression in a human wound model. Plastic and reconstructive surgery Global open ,7(5). https://dx.doi.org/10.1097\%2FGOX.0000000000002 $\underline{221}$

RODRIGUES, M., KOSARIC, N., BONHAM, C.A., and GURTNER, G.C., 2019. Wound healing: a cellular perspective. Physiological Reviews, 99(1), pp.665706. https://doi.org/10.1152/physrev.00067.2017 
SCARANO, A., SBARBATI, A., AMORE, R., IORIO, E.L., FERRARO, G., MARCHETTI, M., and AMUSO, D., 2021. The role of hyaluronic acid and amino acid against the ageing of the human skin: A clinical and histological study. Journal of Cosmetic Dermatology, 20(7),

pp.2296-2304. https://doi.org/10.1111/jocd.13811

SUDHA, P.N., and ROSE, M.H., 2014. Beneficial effects of hyaluronic acid. Advances in food and nutrition research, 72, pp.137-176.

https://doi.org/10.1016/B978-0-12-800269-8.00009-9

SULTANA, J., MOLLA, M.R., KAMAL, M., SHAHIDULLAH, M., BEGUM, F., and BASHAR, M.A., 2009. Histological differences in wound healing in maxillofacial region in patients with or without risk factors. Bangladesh Journal of Pathology, 24(1), pp.3-8.

https://doi.org/10.3329/bjpath.v24i1.2874

WANG, P., HUANG, B., HORNG, H., YEH, C., and CHEN, Y., 2018. Wound healing. Journal of the Chinese Medical Association, 81(2), pp.94-101. https://doi.org/10.1016/j.jcma.2017.11.002

YILDIRIM, S., ÖZENER, H.Ö., DOĞAN, B., and KURU, B., 2018. Effect of topically applied hyaluronic acid on pain and palatal epithelial wound healing: An examiner-masked, randomized, controlled clinical trial. Journal of periodontology, 89(1), pp.36-45. https://doi.org/10.1902/jop.2017.170105

ZHAO, J.Y., CHAI, J.K., SONG, H.F., ZHANG, J. X.U., M.H., and LIANG, Y.D., 2013. Influence of hyaluronic acid on wound healing using composite porcine acellular dermal matrix grafts and autologous skin in rabbits. International wound journal, 10(5), pp.562-572.https://doi.org/10.1111/j.1742481X.2012.01023.X
How to cite this article:

Ammar M. Rajab; Ghada A. Taqa and Wael T. Al-Wattar, 2022. The Effect of Topically Applied Hyaluronic Acid on Skin Wound Healing in Rabbits . Journal of Applied Veterinary Sciences, 7 (1): 38 - 45. DOI:https://dx.doi.org/10.21608/javs.2021.102235.1111 